\title{
INTEGRACIJA POSLOVA UREDA DRŽAVNE UPRAVE U ŽUPANIJSKU UPRAVU: DOSADAŠNJI REZULTATI
}

Dr. sc. Iva Lopižić*

Izv. prof. dr. sc. Romea Manojlović Toman**
UDK: 353:354(497.5)

353:351.01

DOI: $10.3935 /$ zpfz.71.34.06

Prethodno znanstveno priopćenje

Primljeno: srpanj 2021.

U siječnju 2020. uredi državne uprave kao prvostupanjska tijela državne uprave ukinuti su, a njihovi poslovi povjereni su na obavljanje županijama u njihov preneseni djelokrug. Na temelju polustrukturiranih intervjua s pročelnicima županijskih upravnih tijela za poslove opće uprave ocjenjuju se prvi dosadašnji rezultati ove organizacijske promjene. Preliminarni rezultati na koje upućuju intervjui pokazuju da je ukidanje ureda državne uprave u ispitanim županijama dovelo do boljih materijalnih prava službenika, boljih materijalnih uvjeta rada, nepromijenjenog ili nešto boljeg položaja građana, ali i slabijeg nadzora središnje države nad povjerenim poslovima i jedinicama lokalne samouprave. Neka pitanja su otvorena: utječe li smanjenje broja službenika na kvalitetu rada $i$ hoće li broj službenika opet rasti; kakav je položaj župana $i$ hoće li doći do jačanja politizacije te kakva je buduća uloga županija.

Ključne riječi: ukidanje ureda državne uprave, preneseni djelokrug županija, modeli integracije prenesenih poslova, polustrukturirani intervjui, pročelnici

* Dr. sc. Iva Lopižić, poslijedoktorandica Pravnog fakulteta Sveučilišta u Zagrebu, Trg Republike Hrvatske 14, 10000 Zagreb; iva.lopizic@pravo.hr;

ORCID: orcid.org/0000-0002-1157-0602

* Dr. sc. Romea Manojlović Toman, izvanredna profesorica Pravnog fakulteta Sveučilišta u Zagrebu, Trg Republike Hrvatske 14, 10000 Zagreb; romea.manojlovic@ pravo.hr;

ORCID: orcid.org/0000-0002-0292-0180 


\section{UVOD}

Donošenjem novog Zakona o sustavu državne uprave 2019. ${ }^{1}$ ukinuti su uredi državne uprave kao prvostupanjska tijela državne uprave. Poslovi ureda državne uprave povjereni su na obavljanje županijama u njihov preneseni djelokrug izmjenama niza sektorskih zakona u listopadu 2019. Ta organizacijska promjena predstavlja upravnu decentralizaciju, proces kojim državna vlast na lokalne jedinice prenosi izvršavanje poslova državne uprave, zadržavajući pritom ovlasti regulacije i intenzivnog nadzora nad prenesenim poslovima te financijski teret i odgovornost za njihovo obavljanje. ${ }^{2}$ Prenošenjem državnih poslova u preneseni djelokrug županija u Hrvatskoj su integrirane državna i županijska uprava kao što je to bilo tijekom 90-ih godina 20. stoljeća, no u drukčijem institucionalnom aranžmanu. ${ }^{3}$ Tijekom 90-ih integracija se realizirala kroz personalno integrirani model dekoncentrirane državne uprave u kojoj je župan bio predstavnik državne vlasti u županijama s nizom ovlasti u odnosu na županijske urede kao državna tijela u županijama te ujedno i nositelj izvršne vlasti u županijama. ${ }^{4}$ Integracija se sada realizira kroz model prenesenog djelokruga u kojemu županijska upravna tijela osim svojih samoupravnih poslova obavljaju poslove državne uprave uz odgovornost župana kao nositelja izvršne vlasti u županijama središnjoj vlasti

1 Zakon o sustavu državne uprave, Narodne novine, br. 66/2019. (dalje u tekstu: ZSDU).

2 Upravna decentralizacija stoga se u njemačkoj pravnoj tradiciji naziva lažnom, polovičnom decentralizacijom (unechte Kommunalisierung), za razliku od političke decentralizacije kojom se označava prijenos poslova u samoupravni djelokrug lokalnih jedinica koja je prava, potpuna decentralizacija (echte Kommunalisierung) jer njome lokalne jedinice stječu pravo samostalnog odlučivanja o dodijeljenim javnim poslovima, vidi Kuhlmann, S.; Wollmann, H., Introduction to Comparative Public Administration: Administrative Systems and Reforms in Europe, Edward Elgar, Cheltenham, 2019., str. 161 - 163.

3 U klasifikacijama modela državno-lokalnih odnosa različit intenzitet integracije izražen je kroz razlikovanje odvojenog i mješovitog modela teritorijalne uprave. Kao što naziv sugerira, odnos državne uprave i lokalne samouprave u odvojenom modelu je 'udaljeniji' i 'razdvojeniji', dok je u modelu upravne integracije pravno i institucionalno čvršći, državna uprava i lokalna samouprava su 'povezanije' (Leemans, A. F., Changing Patterns of Local Government, International Union of Local Authorities, Hague, 1970., str. 51 - 55).

4 Vidi opširnije u Koprić, I., Uloga županija u hrvatskom sustavu lokalne samouprave $i$ uprave 1990-ih i perspektive regionalizacije nakon promjena Ustava iz 2000. godine, Hrvatska javna uprava, vol. 3, br. 1, 2001., str. $63-87$. 
za obavljanje prenesenih poslova, čime je državnocentrirana integracija državne i lokalne vlasti zamijenjena lokalnocentriranom varijantom. ${ }^{5}$

Cilj rada je ispitati stavove županijskih pročelnika o prvim rezultatima do kojih je dovela integracija poslova ureda državne uprave u županijsku upravu te definirati faktore koji su potencijalno na te rezultate utjecali. Rad predstavlja segmentiranu evaluaciju koja se temelji na polustrukturiranim intervjuima koji su s pročelnicima upravnih tijela županija za povjerene poslove opće uprave / imovinskopravne poslove provedeni tijekom travnja i svibnja 2021. Rad predstavlja nastavak dosadašnjih istraživanja o efektima ukidanja ureda državne uprave u županijama na obavljanje prenesenih poslova i institucionalni razvoj županija. ${ }^{6}$ U radu se prikazuje tijek ukidanja ureda državne uprave te posebnosti pravnog režima obavljanja poslova državne uprave u prenesenom djelokrugu županija. $\mathrm{Na}$ temelju analize unutarnjeg uređenja županijskih uprava konstruiraju se tri modela koja su županije primijenile za integraciju prenesenih poslova državne uprave. Predstavljaju se rezultati provedenih polustrukturiranih intervjua obrađeni metodom analize okvira, sistematiziraju se zaključci o stavovima ispitanika i stanju u ispitanim županijama koji proizlaze iz provedenih intervjua te se provodi rasprava o dobivenim rezultatima. Rad je uvod i temelj za daljnja obuhvatnija istraživanja u okviru longitudinalne evaluacije učinaka ukidanja ureda državne uprave koja će uključiti širi krug relevantnih aktera i druge metode istraživanja.

\section{UKIDANJE UREDA DRŽAVNE UPRAVE I ŠIRENJE PRENESENOG DJELOKRUGA ŽUPANIJA}

\subsection{Djelokrug i ustrojstvo ureda državne uprave u županijama i županija}

Integriranjem županijskih ureda 2001. uredi državne uprave ustrojeni su kao prvostupanjska tijela državne uprave koja su obavljala poslove državne

5 Wollmann, H., Reforming Local Leadership and Local Democracy: the Case of England, Sweden, Germany and France in Comparative Perspective, Local Government Studies, vol. 34, br. 2, 2008., str. $282-283$.

6 Lopižić, I.; Manojlović Toman, R., Prethodna evaluacija ukidanja ureda državne uprave u županijama, Zbornik Pravnog fakulteta u Zagrebu, vol. 69, br. 5-6, 2019., str. 635 - 670; Lopižić, I.; Manojlović Toman, R., Predictions of State and County Civil Servants Regarding the County State Administration Offices Abolition: Two Sides of the Same Coin?, Central European Public Administration Review, vol. 19, br. 1, 2021., str. 41 - 61. 
uprave iz većeg broja upravnih područja za područje županija. ${ }^{7} \mathrm{Na}$ čelu ureda bio je predstojnik, kojeg je imenovala Vlada na temelju javnog natječaja, a na prijedlog ministra nadležnog za poslove opće uprave. ${ }^{8}$ Pravni položaj i unutarnje ustrojstvo ureda državne uprave u županijama bili su regulirani Vladinim uredbama. Prema Uredbi o unutarnjem ustrojstvu ureda državne uprave u županijama iz 2018. ${ }^{9}$ unutarnje ustrojstvene jedinice ureda bile su službe, kojih je u nekim uredima državne uprave bilo pet, a u nekima četiri. ${ }^{10}$ Radom službi upravljali su voditelji službi. ${ }^{11} \mathrm{Za}$ obavljanje određenih poslova državne uprave iz nadležnosti ureda državne uprave mogle su se u gradovima i općinama koje odredi Vlada na prijedlog predstojnika ureda državne uprave osnivati ispostave ureda državne uprave. ${ }^{12}$ Ispostava ureda državne uprave 2018. bilo je ukupno 89, najviše u Splitsko-dalmatinskoj (11 ispostava), a najmanje u Brodsko-posavskoj i Požeško-slavonskoj županiji (samo jedna ispostava). ${ }^{13}$

Pri uredima se neposredno prije njihova ukidanja obavljalo ukupno 69 poslova, od čega najviše njih iz područja socijalne zaštite (12), unutarnjih poslova / poslova opće uprave (11), obrazovanja (8), pravosuđa (8) i kulture (7). ${ }^{14}$ Ipak, istraživanje o stvarnoj aktivnosti ureda tijekom 2015. pokazalo je kako su uredi u toj godini najviše rješavali o poslovima opće uprave (osobna stanja građana,

7 Čl. 2. i 13. Zakona o izmjenama i dopunama Zakona o sustavu državne uprave, Narodne novine, br. 59/2001. (dalje u tekstu: ZID ZSDU).

8 Čl. 15. ZID ZSDU-a.

9 Uredba o unutarnjem ustrojstvu ureda državne uprave u županijama, Narodne novine, br. 84/2018.

10 Uredi državne uprave u županijama u kojima je sjedište četiriju najvećih hrvatskih gradova (Zagrebačka, Primorsko-goranska, Osječko-baranjska i Splitsko-dalmatinska županija) imali su pet ustrojstvenih jedinica (Službu za gospodarstvo, Službu za društvene djelatnosti, Službu za opću upravu, Službu za imovinskopravne poslove, Službu za zajedničke poslove), dok su se u ostalim uredima državne uprave poslovi vezani uz gospodarstvo i imovinskopravni poslovi obavljali u okviru jedinstvene Službe za gospodarstvo i imovinskopravne poslove.

11 Čl. 13. st. 5. Uredbe o unutarnjem ustrojstvu ureda državne uprave u županijama.

12 Čl. 59. Zakona o sustavu državne uprave, Narodne novine, br. 150/2011.

13 Vidi Uredbu o unutarnjem ustrojstvu ureda državne uprave u županijama (Zagrebačka 8; Krapinsko-zagorska- 5, Sisačko-moslavačka 6, Karlovačka 5, Varaždinska 3, Koprivničko-križevačka 2, Bjelovarsko-bilogorska 4, Primorsko-goranska 8, Ličko-senjska 4, Virovitičko-podravska 3, Požeško-slavonska 1, Brodsko-posavska 1, Zadarska 5, Osječko-baranjska 5, Šibensko-kninska 3, Vukovarsko-srijemska 4, Splitsko-dalmatinska 11, Istarska 7, Dubrovačko-neretvanska 4).

14 Lopižić, I., Uloga ureda državne uprave u hrvatskome upravno-političkom sustavu, Hrvatska i komparativna javna uprava, vol. 20, br. 3, 2020., str. 562 - 563. 
matičarstvo, državljanstvo, udruge, popis birača) (83,1 \% ukupno riješenih predmeta), a zatim iz područja gospodarstva (rudarstvo, obrti, trgovina, ugostiteljstvo, turizam, promet, poljoprivreda, šumarstvo). ${ }^{15}$

Ustavnim izmjenama iz 2000. županije su određene kao jedinice područne (regionalne) samouprave. ${ }^{16}$ Pravni položaj županija uređen je Ustavom Republike Hrvatske ${ }^{17}$ i Zakonom o lokalnoj i područnoj (regionalnoj) samoupravi. ${ }^{18}$ Politička tijela županija su županijska skupština kao predstavničko i župan kao izvršno tijelo. ${ }^{19}$ Ustav kao poslove iz samoupravnog djelokruga županija određuje poslove od područnog (regionalnog) značaja, a osobito poslove koji se odnose na školstvo, zdravstvo, prostorno i urbanističko planiranje, gospodarski razvoj, promet i prometnu infrastrukturu te planiranje i razvoj mreže obrazovnih, zdravstvenih, socijalnih i kulturnih ustanova. ${ }^{20} \mathrm{ZLP}(\mathrm{R}) \mathrm{S}$ poslovima određenim Ustavom dodjeljuje i poslove održavanja javnih cesta, izdavanje građevinskih i lokacijskih dozvola, drugih akata vezanih uz gradnju te provedbu dokumenata prostornog uređenja za područje županije izvan područja velikoga grada te ostale poslove sukladno posebnim zakonima. ${ }^{21}$ Nadležnost županija u navedenim upravnim područjima određena je sektorskim zakonima. ${ }^{22}$

Poslovi samoupravnog djelokruga županija obavljaju se u okviru upravnih tijela čiji je čelnik pročelnik kojeg imenuje župan na temelju javnog natječaja. ${ }^{23}$ Upravna tijela u pravilu se ustrojavaju kao upravni odjeli i upravne službe. ${ }^{24}$

15 Lopižić, I., Dekoncentrirana državna uprava i lokalna samouprava: faktor kapaciteta, u: Musa, A. (ur.), Forum za javnu upravu. Izazovi upravljanja: decentralizacija $i$ dekoncentracija obavljanja javnih poslova, Friedrich Ebert Stiftung i Institut za javnu upravu, Zagreb, 2018., str. 38.

16 Čl. 68. Odluke o proglašenju promjene Ustava Republike Hrvatske, Narodne novine, br. 113/2000.

17 Čl. 128. - 131. Ustava Republike Hrvatske, Narodne novine, br. 56/1990, 135/1997, 08/1998, 113/2000, 124/2000, 28/2001, 41/2001, 55/2001, 76/2010, 85/2010, 05/2014.

18 Zakon o lokalnoj i područnoj (regionalnoj) samoupravi, Narodne novine, br. 33/2001, 60/2001, 129/2005, 109/2007, 125/2008, 36/2009, 36/2009, 150/2011, 144/2012, 19/2013, 137/2015, 123/2017, 98/2019, 144/2020. (dalje u tekstu: ZLP(R)S).

19 Čl. 27. i 39. ZLP(R)S-a.

20 Čl. 129.a Ustava RH.

${ }^{21}$ Čl. 20. ZLP(R)S-a.

22 Vidi Škarica, M., Interplay Between the Tiers in Croatian Local Government: Who Is Winning the Interdependence Game, Hrvatska i komparativna javna uprava, vol. 20, br. 2, 2020., str. $207-240$.

23 Čl. 53a ZLP(R)S-a.

24 Čl. 53. ZLP(R)S-a. 
ZLP(R)S određuje kako se za obavljanje određenih poslova iz samoupravnog djelokruga mogu osnovati upravna tijela i izvan sjedišta županije. ${ }^{25}$ Tu zakonsku mogućnost iskoristile su Istarska županija, čiji su upravni odjeli dislocirani u šest gradova, i Vukovarsko-srijemska županija, čiji su upravni odjeli smješteni u Vukovaru i Vinkovcima. Dio poslova koje su županije preuzele od ureda državne uprave 2007. (izdavanje građevinskih dozvola i ostalih akata vezanih uz gradnju) obavlja se u lokalnim jedinicama na području županije, iako ZLP(R)S ne predviđa mogućnost dekoncentracije obavljanja poslova županijske uprave osnivanjem ispostava županijske uprave.

\subsection{Posebnosti pravnog režima obavljanja poslova u prenesenom djelokrugu}

Poslovi ureda državne uprave preneseni su županijama izmjenama 61 sektorskog zakona u listopadu 2019. Izmjene sektorskih zakona stupile su na snagu 1. siječnja 2020. kad su uredi državne uprave prestali s radom. Županijama su povjereni svi poslovi ureda državne uprave uz iznimku poslova provođenja upravnog i inspekcijskog nadzora, koje su preuzela središnja tijela državne uprave. ${ }^{26}$ Tom organizacijskom promjenom djelokrug županija uz poslove samoupravnog (izvornog) djelokruga proširio se poslovima koje obavljaju za državnu vlast u prenesenom (povjerenom) djelokrugu. Obavljanje poslova u prenesenom djelokrugu razlikuje se od obavljanja poslova u samoupravnom djelokrugu po četiri dimenzije: regulaciji, odgovornosti, financiranju i nadzoru. ${ }^{27}$

Temeljna razlika samoupravnih i prenesenih poslova odnosi se na regulacijske ovlasti županija. Samoupravni djelokrug županije samostalno reguliraju odlučivanjem županijske skupštine odnosno odlučivanjem građana putem instrumenata neposredne demokracije (referendum, građanska inicijativa). U odnosu na prenesene poslove, županije nemaju ovlast regulacije, već je regulacija pridržana središnjoj državnoj vlasti. Druga razlika odnosi se na odgovornost. Za obavljanje poslova iz samoupravnog djelokruga odgovaraju župan i županijska skupština neposredno građanima kao biračima i donositeljima političkih odlu-

25 Čl. 55. ZLP(R)S-a.

26 Jedinicama lokalne i područne (regionalne) samouprave mogu se povjeriti jedino državni poslovi neposredne provedbe zakona u prvom stupnju i drugi upravni i stručni poslovi (čl. 33. ZSDU-a).

27 Koprić, I. et al., Upravna znanost - javna uprava u suvremenom europskom kontekstu, Pravni fakultet Sveučilišta u Zagrebu i Studijski centar za javnu upravu i javne financije, Zagreb, 2021., str. $300-302$. 
ka. S druge strane, za obavljanje povjerenih poslova odgovornost mora zadržati središnja država. Ipak, u stvarnosti je građanima teško razlučiti tko je odgovoran za koji posao te često i prenesene poslove doživljavaju kao odgovornost župana i županije. Prema ZLP(R)S-u, odgovornost središnjoj vlasti za zakonito i pravilno obavljanje prenesenih poslova snosi župan ${ }^{28}$, koji usmjerava i nadzire rad upravnih tijela u kojima se obavljaju preneseni poslovi ${ }^{29}$, što sugerira da središnja država uspijeva dio odgovornosti prenijeti na županije. Treća razlika odnosi se na financiranje: poslovi samoupravnog djelokruga financiraju se iz županijskog proračuna, dok se dio sredstava za financiranje prenesenih poslova osigurava u državnom proračunu. Zakonom o izvršavanju Državnog proračuna Republike Hrvatske za 2021. određeno je kako Ministarstvo pravosuđa i uprave dodjeljuje pomoć županijama za obavljanje povjerenih poslova. Riječ je o nenamjenskim sredstvima koja se mogu iskoristiti za isplatu plaća i materijalnih troškova za obavljanje povjerenih poslova. ${ }^{30}$ Županije su dužne izvještavati Ministarstvo pravosuđa i uprave o broju zaposlenih na povjerenim poslovima, što je kriterij za dodjelu sredstava, i o ukupnom utrošku doznačenih sredstava. ${ }^{31} \mathrm{U}$ državnom proračunu za 2021. predviđeno je 309.000.000,00 kn za financiranje troškova prenesenog djelokruga županija ${ }^{32}$, što je oko $15.000 .000,00$ kn manje u odnosu na proračun ureda državna uprave u županijama u 2018. ${ }^{33}$ Posljednja razlika očituje se u nadzornim ovlastima državne vlasti u odnosu na samoupravne i prenesene poslove. Dok je nadzor nad samoupravnim poslovima ograničen na nadzor nad ustavnosti i zakonitosti, obavljanje prenesenih poslova nadzire se u okviru upravnog nadzora. Prema ZSDU-u, upravni nadzor provode središnja tijela državne uprave koja u okviru provođenja nadzora nadziru zakonitost općih akata, zakonitost i pravilnost rada te postupanja prema građanima i drugim strankama te osposobljenost službenih osoba za neposredno obavljanje poslova državne uprave. ${ }^{34}$ Novim ZSDU-om odredbe o nadzoru nad prenesenim poslovima usklađene su s odredbama Europske povelje o lokalnoj samoupravi koja

28 Čl. 42. ZLP(R)S-a.

Čl. 27. st. 1. i 3. Zakona o izvršavanju Državnog proračuna Republike Hrvatske za 2021. godinu, Narodne novine, br. 34/2020 (dalje u tekstu: ZIDPRH).

Ministarstvo financija, Izvještaj o izvršenju državnog proračuna 2021., https://mfin.gov. hr/proracun-86/drzavni-proracun-2021-godina/3116 (1. lipnja 2021.).

33 Ministarstvo financija, Izvještaj o izvršenju državnog proračuna 2018., https://mfin.gov. hr/UserDocsImages/dokumenti/proracun/drzavni2018/Posebni\%20dioR18..pdf (1. lipnja 2021.). 
određuje kako nadzor nad prenesenim poslovima uz nadzor nad zakonitosti i ustavnosti može obuhvatiti nadzor nad svrsishodnošću. Regulacija upravnog nadzora nad prenesenim poslovima prema prijašnjim zakonima o sustavu državne uprave prelazila je nadzor nad svrhovitosti i sadržavala ovlasti koje su karakteristične za hijerarhijski nadzor, što je bilo predmet kritika Vijeća Europe u izvještajima o stanju lokalne samouprave u Hrvatskoj. ${ }^{35}$

\subsection{Integracija poslova i službenika ureda državne uprave u županijsku upravu - istraživanje institucionalnog uređenja}

Proces integracije predmeta, pismohrane, ostale dokumentacije, opreme i sredstava za rad ureda državne uprave u mjesno nadležnu županijsku upravu proveo se sporazumom koji su župani sklopili s Ministarstvom uprave na temelju odluke županijskih skupština. Zaposlenicima ureda državne uprave ponuđena je mogućnost da se izjasne o sporazumnom prestanku službe i ostvare pravo na otpremninu ako su do 31. prosinca 2025. stjecali uvjete za starosnu mirovinu. ${ }^{36} \mathrm{Na}$ bivše zaposlenike ureda primjenjuje se sad Zakon o službenicima i namještenicima u lokalnoj i područnoj (regionalnoj) samoupravi. ${ }^{37}$ Zakon u većoj mjeri prati odredbe Zakona o državnim službenicima ${ }^{38}$, pa je status službenika ureda prelaskom u županijsku upravu ostao u većoj mjeri nepromijenjen. Jedina promjena odnosi se na plaće koje su u županijama nešto veće u odnosu na plaće koje su primali u uredima te neujednačenost platnog sustava među županijama koje imaju široku autonomiju u određivanju plaća. ${ }^{39}$

Prema analizi odluka o ustrojstvu i djelokrugu upravnih tijela županija, donesenih uoči preuzimanja poslova državne uprave krajem 2019., identificiraju se tri modela koje su županije primijenile za organizaciju obavljanja prenesenih poslova: odvojeni model u kojem upravni odjeli obavljaju isključivo poslove samoupravnog odnosno prenesenog djelokruga, integrirani model u kojem se poslovi samoupravnog i prenesenog djelokruga obavljaju u okviru istih upravnih odjela

35 Kongres lokalnih i regionalnih vlasti, Local and Regional Democracy in Croatia, CG31(2016)11 final 20 October 2016, 2016., str. 20 - 21.

36 Čl. 67. st. 4. ZSDU-a.

37 Zakon o službenicima i namještenicima u jedinicama lokalne i područne (regionalne) samouprave, Narodne novine, br. 86/2008, 61/2011, 04/2018, 112/2019.

38 Marčetić, G., Novo lokalno službeničko zakonodavstvo i upravljanje ljudskim potencijalima u reformiranoj lokalnoj samoupravi, u: Koprić, I. (ur.), Reforma lokalne i regionalne samouprave u Hrvatskoj, Pravni fakultet Sveučilišta u Zagrebu i Studijski centar za javnu upravu i javne financije, Zagreb, 2013., str. 194 - 196.

39 Ibid., str. 197 - 199. 
te mješoviti model $\mathrm{u}$ kojem se dio prenesenih poslova obavlja u upravnim odjelima u kojima se obavljaju i poslovi samoupravnog djelokruga, a dio u okviru upravnih odjela koji obavljaju isključivo poslove prenesenog djelokruga. Kategorizacija modela omogućuje mjerenje razine organizacijske integracije državnih i županijskih poslova: najmanja mjera integracije postoji u odvojenom, nešto je veća u mješovitom, a najveća je u integriranom modelu. Analiza pokazuje da se 15 županija opredijelio za mješoviti model, njih četiri za integrirani model, a samo jedna za odvojeni model organizacije obavljanja prenesenih poslova. Broj upravnih tijela u nekim županijama je znatno (tri županije) odnosno neznatno (12 županija) porastao, u nekima je ostao isti (dvije županije), a u nekima je neznatno (dvije županije) odnosno znatno (jedna županija) smanjen. Tom organizacijskom promjenom županije su dobile dislocirane urede (bivše ispostave ureda državne uprave).

Odvojeni model primijenjen je jedino u Zadarskoj županiji, u kojoj je ustrojen Upravni odjel za povjerene poslove državne uprave Zadarske županije. Županije koje su primijenile mješoviti model su u pravilu ustrojile poseban upravni odjel za obavljanje poslova opće uprave i imovinskopravne poslove, dok su ostale prenesene poslove integrirale $\mathrm{u}$ upravne odjele u kojima se obavljaju poslovi samoupravnog djelokruga. Iznimka je Splitsko-dalmatinska županija, koja ima tri upravna odjela za obavljanje prenesenih poslova: Upravni odjel za branitelje, civilnu zaštitu i ljudska prava, Upravni odjel za opću upravu i Upravni odjel za imovinskopravne poslove, od čega je samo na čelu Upravnog odjela za branitelje, civilnu zaštitu i ljudska prava predstojnik iz reda županijskih službenika, dok su pročelnici iz ostalih odjela iz redova bivših službenika ureda državne uprave u županijama (UDUŽ), što se uzima kao relevantno za podjelu. Kako se pretežiti dio poslova ureda državne uprave odnosio na poslove opće uprave, mješoviti model je po razini organizacijske integracije bliži odvojenom modelu jer se samo manji dio ukupnih poslova ureda obavlja u okviru upravnih tijela za samoupravne poslove.

Upravni odjeli u kojima nisu integrirani poslovi prenesenog djelokruga $\mathrm{u}$ većini su županija ured župana, služba županijske skupštine, upravni odjel za financije i služba za unutarnju reviziju te upravni odjeli za poslove vezane uz izdavanja građevinskih dozvola, prostorno planiranje i zaštitu okoliša. Riječ je o upravnim odjelima koji u najvećoj mjeri obavljaju poslove unutarnjih upravnih funkcija, odnosno upravnim odjelima koji obavljaju poslove koji su prijašnjim decentralizacijskim mjerama u cijelosti dodijeljeni županijama. ${ }^{40}$ Osim navedenih upravnih odjela, jedino Istarska i Zagrebačka županija imaju još dva

40 Svi poslovi ureda državne uprave vezani uz gradnju i prostorno planiranje su s ureda državne uprave na županijska tijela preneseni Zakonom o prostornom uređenju 
odjela koji obavljanju isključivo poslove samoupravnog djelokruga (Upravni odjel za talijansku nacionalnu zajednicu i druge etničke skupine u Istarskoj te Upravni odjel za fondove Europske unije, regionalnu i međunarodnu suradnju u Zagrebačkoj županiji).

Pročelnici upravnih tijela u kojima se obavljaju preneseni poslovi državne uprave u nekim su županijama pročelnici iz županija, a u nekima bivši zaposlenici ureda državne uprave (u pravilu predstojnici i voditelji službi za poslove opće uprave/imovinskopravne poslove). Uz kriterij primijenjenog modela organizacije obavljanja prenesenih poslova, podrijetlo pročelnika upravnih odjela u kojima se obavljaju preneseni poslovi drugi je kriterij za mjerenje razine integracije državnih poslova u županijsku upravu. Prema tom kriteriju veća razina integracije je u onim županijama u kojima su pročelnici upravnih tijela obavljali funkciju pročelnika u županijama nego u onim županijama u kojima su pročelnici upravnih tijela bivši zaposlenici ureda državne uprave.

Tablica I: Modeli organizacije obavljanja prenesenih poslova

\begin{tabular}{|c|c|c|c|}
\hline \multicolumn{2}{|r|}{ model } & pročelnik & županije \\
\hline \multicolumn{2}{|l|}{ odvojeni } & UDUŽ & Zadarska \\
\hline \multirow[t]{3}{*}{ mješoviti } & $\begin{array}{l}\text { opća uprava, imovinskopravni } \\
\text { poslovi i branitelji }\end{array}$ & UDUŽ & Vukovarsko-srijemska \\
\hline & $\begin{array}{l}\text { opća uprava i imovinskopravni } \\
\text { poslovi }\end{array}$ & UDUŽ & $\begin{array}{l}\text { Bjelovarsko-bilogorska } \\
\text { Brodsko-posavska } \\
\text { Istarska } \\
\text { Karlovačka } \\
\text { Koprivničko-križevačka } \\
\text { Krapinsko-zagorska } \\
\text { Međimurska } \\
\text { Požeško-slavonska } \\
\text { Splitsko-dalmatinska } \\
\text { Sisačko-moslavačka } \\
\text { Varaždinska } \\
\end{array}$ \\
\hline & opća uprava & UDUŽ & $\begin{array}{l}\text { Ličko-senjska županija } \\
\text { Šibensko-kninska } \\
\text { Osječko-baranjska }\end{array}$ \\
\hline \multicolumn{2}{|l|}{ integrirani } & Županijski & $\begin{array}{l}\text { Dubrovačko-neretvanska } \\
\text { Primorsko-goranska } \\
\text { Virovitičko-podravska } \\
\text { Zagrebačka }\end{array}$ \\
\hline
\end{tabular}

Izvor: autorice

i gradnji, Narodne novine, br. 76/2007, a svi poslovi zaštite okoliša i prirode izmjenama Zakona o zaštiti okoliša, zraka i prirode tijekom razdoblja od 2007. do 2013. 


\section{ISTRAŽIVANJE}

Tijekom travnja i svibnja 2021. provedeni su polustrukturirani intervjui s pročelnicima upravnih odjela u kojima se obavljaju preneseni poslovi opće uprave / imovinskopravni poslovi kao najzastupljenija kategorija poslova koje su obavljali uredi državne uprave. Riječ je pretežito o poslovima vezanim uz osobna stanja građana i matičarstvo, udruge i vođenje registra birača. Kriteriji za odabir županija bili su teritorijalna lokacija (podjednaka zastupljenost županija jadranske i kontinentalne Hrvatske), primijenjeni model (odvojeni, mješoviti ili integrirani) te status pročelnika (je li funkciju županijskog pročelnika već obavljao u županiji ili je na tu funkciju došao iz ureda državne uprave). U istraživanju je sudjelovalo devet pročelnika, od čega četiri pročelnika koji su pročelničku funkciju obavljali u županijama prije integracije poslova državne uprave, i pet pročelnika koji su vršili funkciju predstojnika ili voditelja službi u uredima državne uprave. Istraživanjem su obuhvaćene četiri županije jadranske i pet županija kontinentalne Hrvatske.

Istraživanje se nastavlja na dosadašnja istraživanja o ukidanju ureda državne uprave u županijama. ${ }^{41}$ Cilj intervjua bio je ispitati stavove pročelnika o dosadašnjim rezultatima ukidanja ureda državne uprave te je stoga izabrana tehnika polustrukturiranih intervjua u kojima je ispitanicima dana mogućnost da iznesu svoje viđenje stvari i šire od postavljenih pitanja. Iako su se od ispitanika tražili objektivni podaci, naglasak je u prvom redu na njihovim stavovima o provedenoj organizacijskoj promjeni. Pitanjima su pokrivena tri tematska područja:

1) Tijek procesa preuzimanja poslova, status službenika i praktični problemi - ispitanici su objasnili tijek preuzimanja poslova ureda od strane županija (je li proces bio planiran, koliko su bili uključeni, koliko je trajao) i dosadašnje rezultate u pogledu statusa preuzetih zaposlenika (je li se broj službenika smanjio ili povećao, je li se to odrazilo na obavljanje posla, jesu li službenici mijenjali lokaciju, jesu li im se mijenjali uvjeti zaposlenja i materijalna/ nematerijalna prava). Ispitanici su naveli i dosadašnje najveće probleme i izazove u provedbi organizacijske promjene. ${ }^{42}$

${ }^{41}$ Riječ je o radovima o prethodnoj evaluaciji ukidanja ureda državne uprave u županijama (Lopižić; Manojlović Toman, Prethodna evaluacija..., op. cit. u bilj. 6); ispitivanju subjektivnih faktora koji uvjetuju razlike u predviđanjima državnih i županijskih službenika o efektima ukidanja ureda državne uprave (Lopižić; Manojlović Toman, Predictions..., op. cit. u bilj. 6) te formuliranju hipoteza o utjecaju širenja prenesenog djelokruga na obavljanje prenesenih poslova i institucionalni razvoj Županija (Lopižić, I., Preneseni djelokrug u lokalnoj samoupravi: teorijska razmatranja $i$ komparativna iskustva, 2021., rad u postupku objave).

Vidi pitanja 1. - 3. i 5. Upitnika u Dodatku 1. 
2) Integracija prenesenih poslova, horizontalna $i$ vertikalna integracija - ispitanici su objasnili razlike u samoupravnim i prenesenim poslovima, mogućnost njihove integracije i utjecaj na svakodnevni rad te naveli jesu li se opseg i intenzitet suradnje s drugim tijelima unutar županije i tijelima središnje državne uprave promijenili i u kojim aspektima. ${ }^{43}$

3) Subjektivna ocjena o dosadašnjim efektima ove organizacijske promjene - ispitanici su naveli jesu li se ispunila njihova početna očekivanja od ukidanja ureda državne uprave, ocjenu provedbe njihova ukidanja te utjecaj ukidanja ureda na položaj i status građana. ${ }^{44}$

Podaci prikupljeni polustrukturiranim intervjuima obrađeni su metodom tzv. analize okvira (framework analysis), kvalitativnom metodom prikupljanja i obrade podataka razvijenoj 80 -ih godina 20. stoljeća u Nacionalnom centru za društvena istraživanja u SAD-u, koja se danas široko upotrebljava u društvenim istraživanjima. ${ }^{45}$ Središnja komponenta ove metode jesu tematski okviri (thematic framework) koji omogućuju da se podaci sistematiziraju u unaprijed određene teme, uz veći ili manji broj podtema. Podaci dobiveni od svakog ispitanika zatim se uvrštavaju unutar odgovarajuće teme, što omogućuje analizu i interpretaciju podataka te stvaranje zaključaka za svako tematsko područje. ${ }^{46}$ Taj postupak je deduktivan jer su tematska područja unaprijed određena te istraživač donosi zaključke o svakome području na osnovi prikupljenih podataka. Ipak, ta metoda omogućuje i identificiranje novih tema koje nisu bile početno uvrštene u tematske okvire, ali su se pojavile tijekom provođenja istraživanja ${ }^{47}$ Metoda analize okvira primijenjena je i u nekim drugim hrvatskim društvenim istraživanjima o rezultatima organizacijskih promjena. ${ }^{48} \mathrm{U}$ ovome je radu analiza okvira primijenjena tako da su najprije identificirana tri tematska područja s njihovim podtemama (okvirima, vidi tablice $2-4$ ). Nakon toga provedeni su intervjui i izrađeni transkripti svakog intervjua, dužine tri do četiri stranice teksta. Odgovori ispitanika uvršteni su u okvire na osnovi kojih su autorice provele

43 Vidi pitanja 4. - 6. Upitnika u Dodatku 1.

44 Vidi pitanja 7. - 8. Upitnika u Dodatku 1.

45 Ritchie, J.; Spencer, L.; O’Connor, W., Carrying out Qualitative Analysis, u: Ritchie, J.; Lewis, J. (ur.), Qualitative Research Practice - A Guide for Social Science Students and Researchers, SAGE Publications, London, 2003., str. 220.

46 Ibid., str. $219-220$.

47 Ajduković, M.; Urbanc, K., Kvalitativna analiza iskustva stručnih djelatnika kao doprinos evaluaciji procesa uvođenja novog modela rada u centre za socijalnu skrb, Ljetopis socijalnog rada, vol. 17, br. 3, 2010., str. 329.

48 Primjerice Ajduković i Urbanc su je primijenile kod analize iskustva stručnih djelatnika prilikom uvođenja novog modela rada u centre za socijalnu skrb (ibid.). 
analizu i stvorile generičke zaključke za svaku od podtema. Izvedeni zaključci potkrijepljeni su ilustrativnim izjavama ispitanika (popis izjava, vidi Dodatak 2), a kako bi se zajamčila anonimnost, odgovori ispitanika kodirani su te se uz njih ne navode ime ili županija, već generički podatak ISPI-9 (ispitanik l -9).

\section{REZULTATI ISTRAŽIVANJA}

\subsection{Tijek i dosadašnji rezultati ukidanja ureda državne uprave}

Analiza provedenih intervjua pokazala je da postoji suglasnost među intervjuiranim pročelnicima o tome da je proces ukidanja ureda državne uprave i preuzimanje poslova od strane županija proveden participativno, uz suradnju i sastanke predstavnika Ministarstva uprave, ureda državne uprave, župana, županijskih pročelnika i Hrvatske zajednice županija (Izjava 1, Izjava 2) ${ }^{49}$. Broj zaposlenika koji su obavljali poslove u uredima državne uprave je u svim županijama obuhvaćenim istraživanjem smanjen. Smanjenje u većini tih županija iznosi između 20 \% i $25 \%$, uz dvije izrazite iznimke: jedne županije u kojoj je smanjenje iznosilo $4 \%$ i jedne u kojoj je iznosilo 50 \% (Izjava 3, Izjava 4). Među ispitanim županijama postoje značajne razlike u vremenu koje je bilo potrebno da se donesu rješenja o rasporedu na radna mjesta preuzetih službenika (Izjava 5, Izjava 6). U pet od devet ispitanih županija došlo je do zapošljavanja novih službenika, no ta su zapošljavanja bila minimalna (najviše deset u jednoj županiji) te ukupni broj službenika nije dosegnuo prijašnji broj zaposlenih u uredu državne uprave (Izjava 7). Dva ispitanika pritom su najavila kako planiraju nova zapošljavanja (Izjava 8). U preostalim županijama zapošljavanja nije bilo (Izjava 9).

Zaposlenici ureda $\mathrm{u}$ ispitanim županijama u pravilu nisu mijenjali svoje fizičko mjesto rada (Izjava 10). Plaće zaposlenika porasle su (ponegdje uz iznimku pročelnika, čije su plaće nešto manje nego što su bile plaće predstojnika ureda državne uprave), no uz neujednačenost među ispitanim županijama. Neki ispitanici naveli su kako zaposlenici ureda imaju iste plaće i koeficijente kao i županijski službenici (Izjava 11), neki kako su plaće zaposlenika ureda ostale manje nego plaće županijskih službenika (Izjava 12), a neki kako plaće trenutačno nisu izjednačene, ali bi u budućnosti mogle postati (Izjava 13). Ipak, ispitanici u ovih devet županija smatraju da su zaposlenici preuzeti iz ureda državne uprave uglavnom zadovoljni jer su im se materijalna primanja (npr. veće plaće, olakšano zapošljavanje tijekom godine, dnevnice i topli obroci, veća dostupnost edukacija) barem u nekoj mjeri poboljšala (Izjava 14). Stavovi

49 Vidi izjave u Dodatku 2. 
ispitanika o pitanju integracije službenika u županijsku upravu su podijeljeni. Neki ispitanici smatraju da se ona u cijelosti dogodila (Izjava 15, Izjava 16), dok neki smatraju kako se osjeti jasna podjela na dotadašnje službenike ureda i službenike županija (Izjava 17).

Ispitanici su istaknuli i praktične probleme koji su se pojavili nakon integracije poslova državne uprave u njihovim županijama. Veći dio ispitanika kao problem je istaknuo pisarnice i uredsko poslovanje (Izjava 18), problem organizacije rada u ispostavama i potrebu za izmjenama ZLP(R)S-a, kojima će se županijama omogućiti osnivanje ispostava (Izjava 19). Neki ispitanici kao problem su istaknuli i odljev službenika (Izjava 20), osobito onih koji su obavljali poslove matičarstva i pronalazak novih kvalitetnih kadrova za obavljanje tih poslova (Izjava 21).

Tablica 2: Rezultati istraživanja - tematsko područje I

\begin{tabular}{|l|l|l|}
\hline tematsko područje & okvirni zaključci \\
\hline Tematsko područje & Tijek & - suradnja dionika \\
\cline { 2 - 3 } 1 - Tijek i dosadašnji & status službenika & - smanjenje broja službenika \\
rezultati ukidanja & & - nova zapošljavanja u pet od devet županija \\
ureda državne uprave & & - veće plaće i bolji materijalni uvjeti rada \\
& & - neujednačenost među županijama u \\
& & plaćama \\
\cline { 2 - 3 } & praktični problemi & - pisarnice i uredsko poslovanje \\
& & - ispostave \\
& & - matičari \\
\hline
\end{tabular}

Izvor: autorice

\subsection{Integracija prenesenih poslova, horizontalna i vertikalna integracija}

U pogledu modela integracije prenesenih poslova većina ispitanika smatra da sve poslove državne uprave nije dobro integrirati u poseban upravni odjel (Izjava 22, Izjava 23), već po kriteriju sadržaja posla (Izjava 24). Troje ispitanika pak smatra da je model izdvajanja poslova državne uprave u jedinstveni upravni odjel bolja organizacijska varijanta (Izjava 25). Ispitanici kod kojih je primijenjen integrirani model navode da je to početno dovelo do otežavanja posla pročelnicima koji su se morali priviknuti na nove poslove i na značajno povećan broj službenika, koji se negdje povećao i za 100 \% (Izjava 26). Ispitanik koji je radio u uredu državne uprave je pak istaknuo kako je upravo okolnost da je na mjestu pročelnika osoba iz ureda službenicima olakšala integraciju u županijsku upravu (Izjava 27). U nekim od ispitanih županija službenici ureda su naučili obavljati nove poslove (uglavnom poslove državne uprave koje su dotad obavljali 
drugi službenici), a u nekim županijama su županijski službenici obučeni za obavljanje prenesenih poslova. Što se tiče odnosa prenesenih i samoupravnih poslova, svi ispitanici navode velike razlike između te dvije skupine poslova i teškoće kod njihove integracije (Izjava 28, Izjava 29, Izjava 30).

Koordinacija među županijskim upravnim tijelima ostvaruje se kroz sastanke kolegija pročelnika. Pritom je troje ispitanika kod kojih postoje odvojeni upravni odjeli s prenesenim poslovima istaknulo nezainteresiranost pročelnika drugih upravnih tijela za stanje u njihovu području (Izjava 31, Izjava 32, Izjava 33). Samo je jedan ispitanik naveo kako su nakon ukidanja ureda provedeni razgovori s lokalnim jedinicama, što upućuje na nepromijenjenu koordinaciju s lokalnim jedinicama na području županija (Izjava 34). Ispitanici su suglasni oko slabog nadzora središnje države nad obavljanjem poslova (Izjava 35, Izjava 36), u prvom redu oko toga da ne postoji jednoobrazan način kontrole i podnošenja izvješća (Izjava 37). Ispitanici smatraju i kako se suradnja s resornim ministarstvima nije promijenila u odnosu na prije i kako ona u najvećoj mjeri ovisi o neformalnim odnosima službenika sa službenicima središnjih tijela (Izjava 38, Izjava 39, Izjava 40). Jedan ispitanik posebno je istaknuo kako se ukidanjem ureda državne uprave značajno smanjio i nadzor nad lokalnim jedinicama, koji sad provode središnja tijela državne uprave (Izjava 4l).

Tablica 3: Rezultati istraživanja - tematsko područje 2

\begin{tabular}{|l|l|l|}
\hline \multicolumn{2}{|l|}{ tematsko područje } & okvirni zaključci \\
\hline $\begin{array}{l}\text { Tematsko područje } \\
\text { 2- Integracija } \\
\text { prenesenih poslova, } \\
\text { horizontalna i } \\
\text { vertikalna integracija }\end{array}$ & $\begin{array}{l}\text { integracija samoupravnih } \\
\text { i prenesenih poslova }\end{array}$ & $\begin{array}{l}\text { - velike razlike u vrsti samoupravnih i } \\
\text { prenesenih poslova }\end{array}$ \\
\cline { 2 - 3 } & $\begin{array}{l}\text { horizontalna } \\
\text { koordinacija }\end{array}$ & $\begin{array}{l}\text { sastanci kolegija pročelnika } \\
\text { - nepromijenjena koordinacija s lokalnim } \\
\text { jedinicama na području županije }\end{array}$ \\
\cline { 2 - 3 } & vertikalna koordinacija & $\begin{array}{l}\text { - oslabljen nadzor središnje države } \\
\text { suradnja sa središnjim tijelima kroz } \\
\text { neformalne kontakte službenika }\end{array}$ \\
\hline
\end{tabular}

Izvor: autorice

\subsection{Subjektivna ocjena ispitanika o dosadašnjim efektima ukidanja ureda državne uprave}

U pogledu subjektivne ocjene provedene organizacijske promjene ispitanici navode da je ona ostvarila njihova očekivanja te da u načelu u njihovim županijama nije polučila negativne efekte (Izjava 42). Međutim, neki ispitanici istaknuli su nedostatke u samoj koncepciji organizacijske promjene. Dva ispitanika kao 
problem su istaknula kako ukidanje ureda nije bilo predviđeno u strateškim dokumentima o razvoju hrvatske javne uprave i kako nije bilo stručno vođeno (Izjava 43, Izjava 44). S druge strane, dva ispitanika rekla su kako je dobro što se ukidanje ureda brzo provelo jer bi se u suprotnom od toga možda odustalo (Izjava 45, Izjava 46). Tri ispitanika istaknula su kako decentralizacija poslova nije u cijelosti prikladna jer su poslove ureda mogle preuzeti druge organizacije (Izjava 47), odnosno jer županije ovom decentralizacijom opet nisu dobile poslove koji su za njih bitne (Izjava 48). Kao koncepcijski problem u ovoj organizacijskoj promjeni jedan je ispitanik istaknuo gušenje samoupravne uloge županije, što je protivno ustavnoj intenciji o ulozi županija u Hrvatskoj (Izjava 49). Prema mišljenju nekih ispitanika provedbu ove organizacijske promjene olakšali su prijašnji odnosi suradnje sa županijom (Izjava 50, Izjava 51).

Svih devet ispitanika suglasno je kako je ovom organizacijskom promjenom ojačan položaj županija (Izjava 52) i župana (Izjava 53, Izjava 54). Neki ispitanici, štoviše, smatraju i kako je pravi cilj reforme bilo očuvanje županija (Izjava 55, Izjava 56). Ispitanici za sada nisu uočili upletanje župana u obavljanje prenesenih poslova državne uprave, no svjesni su da u slučaju promjene osobe župana takva mogućnosti postoji (Izjava 57). Neki ispitanici istaknuli su i kako se poslovi ureda sastoje od provedbe zakona zbog čega je i mogućnost interferencije župana u rješavanje pojedinačnih upravnih stvari vrlo ograničena (Izjava 58, Izjava 59).

Što je najbitnije, ispitanici navode da nije bilo većih promjena u pogledu pružanja usluga građanima (Izjava 60), uz ispitanike koji navode da se usluge sada mogu dobiti na jednome mjestu (Izjava 61) ili da je sustav građanima malo jasniji i brži (Izjava 62), odnosno da je bolji zbog informatizacije rada županija (Izjava 63).

Tablica 4: Rezultati istraživanja - tematsko područje 3

\begin{tabular}{|c|c|c|}
\hline \multicolumn{2}{|l|}{ tematsko područje } & okvirni zaključci \\
\hline \multirow{3}{*}{$\begin{array}{l}\text { Tematsko područje } \\
3 \text { - Subjektivna } \\
\text { ocjena o dosadašnjim } \\
\text { efektima }\end{array}$} & dosadašnja očekivanja & - ispunjena \\
\hline & $\begin{array}{l}\text { položaj i uloga županija } \\
\text { i župana }\end{array}$ & \begin{tabular}{|l} 
- \\
županije su ojačane \\
jača uloga župana, iako za sada bez \\
upletanja u rad prenesenih poslova
\end{tabular} \\
\hline & položaj građana & $\begin{array}{l}\text { - nepromijenjen ili neznatno poboljšan } \\
\text { u brzini i pružanju usluga na jednome } \\
\text { mjestu }\end{array}$ \\
\hline
\end{tabular}

Izvor: autorice 


\section{RASPRAVA O REZULTATIMA ISTRAŽIVANJA}

Rezultati istraživanja pokazali su da je ispitanim županijama zajedničko smanjenje broja službenika koji obavljaju poslove državne uprave. U većini ispitanih županija smanjenje se kreće za oko 20 do $25 \%$. Prema izjavama ispitanika, za sada ni u jednoj županiji nova zapošljavanja nisu dosegnula broj zaposlenih prije ukidanja ureda državne uprave. Taj podatak govori u prilog racionalizaciji u obavljanju poslova državne uprave, što je bio jedan od proklamiranih ciljeva ukidanja ureda državne uprave. Okolnost da jedna županija u kojoj se broj službenika na poslovima državne uprave smanjio za čak 50 \% nije zapošljavala nove službenike upućuje da postoji prostor za daljnju racionalizaciju obavljanja poslova državne uprave. Tu okolnost treba tumačiti uzimajući u obzir pandemiju bolesti COVID-19, koja je obilježila 2020. i mogućnost da će normalizacija funkcioniranja dovesti do novog povećanja broja zaposlenih, što se u nekim županijama već planira. Iako su ispitanici isticali nedostatak službenika kao problem, taj su problem uspjeli riješiti tako što su se bivši zaposlenici ureda odnosno županijski službenici obučili za obavljanje dijela poslova državne uprave. Postavlja se pitanje je li to utjecalo na pad kvalitete obavljanja tih poslova, odnosno koji je period prilagodbe tih službenika na obavljanje novih poslova. Ipak, ispitanici u tom pogledu nisu uputili na značajne probleme te su suglasni kako se svi poslovi redovito obavljaju bez štete za interese građana. Potencijalni efekti uključivanja županijskih službenika u obavljanje poslova državne uprave su otežani nadzor i utvrđivanje odgovornosti za obavljanje poslova, a dugoročno i potpuna integracija državnih poslova u županijsku upravu, koja bi mogla potaknuti političku decentralizaciju dijela prenesenih poslova.

Materijalna prava preuzetih službenika u svim su ispitanim županijama prema mišljenju ispitanika poboljšana. Iznimka su pročelnici koji su obavljali funkciju predstojnika ureda državne uprave, čije su se plaće nešto smanjile. Ipak, oni su istaknuli da im se sada opseg posla smanjio jer više ne vode čitav ured. Između županija bilo je velikih razlika u pogledu trenutka kad su službenici dobili rješenja o rasporedu na nova radna mjesta. Ta okolnost mogla je izazvati njihovu nesigurnost, no čini se da do toga u većoj mjeri nije došlo jer su svi barem neformalno znali da će svi službenici ureda koji nisu iskoristili zakonsku mogućnost odlaska u mirovinu biti zadržani. Kao potencijalni problem javlja se situacija da u nekim županijama plaće preuzetih službenika nisu izjednačene s plaćama županijskih službenika. Održavanje ovakve nejednakosti dugoročno može dovesti do jačanja osjećaja nepravednosti od strane preuzetih službenika, a time i pada njihove motivacije za kvalitetno obavljanje poslova. Također, među županijama obuhvaćenim istraživanjem postoji neujednačenost među materijalnim pravima službenika zbog čega službenici koji obavljaju iste 
poslove u različitim županijama imaju velike razlike u primanjima. Navedeno može potencijalno dovesti do veće atraktivnosti rada u županijama s većim primanjima koje će moći privući bolje kandidate za rad u županijskoj upravi.

Ispitanici su većinom suglasni u tome koji su im bili najveći izazovi i problemi pri integraciji ureda u županijsku upravu svojih županija: organizacija rada u ispostavama, ujednačavanje rada pisarnica te nedostatak službenika (osobito matičara) koji su otišli u mirovinu. Neki su ispitanici pritom naglasili prednosti ureda u pogledu organizacije rada po ispostavama, boljeg funkcioniranja pisarnice i kvalitetnije informatičke tehnologije u odnosu na organizaciju i način rada u županijama. Stoga se postavlja pitanje mogu li županije nešto naučiti od ureda, odnosno mora li se integracija ostvariti tako da bivši uredi u cijelosti preuzmu način rada i postupanja županije ili i županije moraju učiti od državne uprave i preuzetih državnih službenika. Provedeni intervjui pokazuju kako se od preuzetih službenika očekivalo uklapanje u županijski način rada te kako se dobra iskustva i prakse rada ureda većinom nisu proširili u rad županijske uprave.

Većina ispitanika smatra da je bolje integrirati prenesene i samoupravne poslove, dok tri ispitanika odvojeni model smatraju boljom organizacijskom varijantom. Može se zaključiti kako odabir modela ovisi koji ciljevi se smatraju poželjnijima. Odvojeni model osigurava bolji nadzor središnje vlasti, vertikalnu koordinaciju i jasniju odgovornost za prenesene poslove. Integrirani model osigurava bolju horizontalnu koordinaciju, veću integraciju sa samoupravnim poslovima te cjelovitiji pristup obavljanju javnih poslova i kreiranju županijskih javnih politika.

Stav ispitanika je kako se u praksi vidi izrazita razlika u vrsti poslova županijskog samoupravnog i prenesenog djelokruga. Upitno je može li širenje prenesenog djelokruga županija poslovima koji funkcionalno nisu povezani s poslovima samoupravnog djelokruga pridonijeti tome da županije zauzmu cjelovitiji pristup obavljanju javnih poslova i kreiranju županijskih javnih politika. Podaci dobiveni intervjuima pokazuju da nadzor središnje države nad obavljanjem poslova prenesenog djelokruga nije usmjeren smanjivanju autonomije županija ni upletanju u druge aspekte njihova rada. S druge strane, kao što je istaknuo jedan od ispitanika, županijama nisu preneseni oni poslovi koji bi im omogućili da jačaju svoju Ustavom zajamčenu ulogu jedinica područne (regionalne) samouprave koje potiču razvoj društvenih i gospodarskih službi na svojem području. Zaključak na koji provedeni intervjui upućuju jest da ispitanici smatraju da se ovom organizacijskom promjenom željelo legitimirati postojanje županija kroz prenošenje poslova i povećanje broja službenika, ali ne i provesti ozbiljna decentralizacija jer je bitan dio javnih poslova i dalje zadržan na državnoj razini.

Problem do kojeg ukidanje ureda potencijalno može dovesti jest pitanje nadzora nad lokalnim jedinicama koji sad obavljaju središnja tijela državne 
uprave. Do sada je nadzor na 556 lokalnih jedinica obavljalo 20 ureda države uprave u županijama, no sada je ta ovlast prepuštena središnjim tijelima. To povlači pitanje kapaciteta ministarstava da nadziru jedinice lokalne samouprave s mogućom posljedicom nezakonitosti i nejednakosti u radu između jedinica lokalne samouprave. Ispravak te situacije ipak se ne bi trebao tražiti u ostavljanju ovlasti nadzora županijama, već ponajprije u teritorijalnom preustroju u kojem bi središnja tijela mogla kontrolirati manji broj lokalnih jedinica.

Što se tiče pitanja u kojima se tražila u većoj mjeri subjektivna ocjena ispitanika o provedenoj organizacijskoj promjeni, rezultati upućuju na to da je većina ispitanika zadovoljna te da su se njihova početna očekivanja u njihovim županijama u većoj mjeri ostvarila. Rezultati provedenih intervjua donekle prate rezultate prethodnog istraživanja ${ }^{50}$, koje je pokazalo da postoji statistički značajna razlika u predviđanjima županijskih pročelnika te predviđanjima predstojnika i voditelja službi ureda države uprave u pogledu efekata ukidanja ureda državne uprave, pri čemu su predviđanja prve skupine bila puno pozitivnija od predviđanja druge skupine. Naime, kod ispitanih pročelnika koji dolaze iz ureda državne uprave ipak se mogao uočiti veći broj problema i prigovora na provedenu organizacijsku promjenu nego kod županijskih pročelnika. Ipak, ispitanim je županijskim pročelnicima preuzimanje prenesenih poslova predstavljalo veći izazov i problem jer su postali odgovorni za čitav niz novih i nepoznatih poslova te su dobili znatan broj novih službenika u svoje upravne odjele, dok su predstojnici i voditelji ureda državne uprave u pravilu nastavili obavljati iste poslove uz smanjen broj službenika ili im je posao smanjen jer više ne vode cijelu organizaciju. Može se stoga zaključiti da je faktor koji je najviše utjecao na oblikovanje njihovih stavova pripadanje vlastitoj organizaciji.

U prethodnim istraživanjima ${ }^{51}$ predviđanje koje je bilo najizraženije kod obiju skupina ispitanika bilo je da će položaj župana jačati te da može doći do politizacije. Provedeni intervjui upućuju na to da ispitanici vide da položaj župana jača, no za sada ne osjećaju upletanje politike ili župana osobno u njihov rad. Stoga politizacija ostaje kao potencijalni problem, no, prema riječima ispitanika, ona se kao realan problem u njihovim županijama (još) nije pojavila.

I napokon, možda je glavno pitanje je li i kako je ukidanje ureda državne uprave utjecalo na građane. Prema mišljenju ispitanika, situacija što se tiče građana potpuno je ista ili neznatno bolja. Ista je u tom smislu što smatraju da su županije osigurale da se poslovi nesmetano obavljaju te da se poslovi obavljaju na istim lokacijama. Bolja je u nekim aspektima brzine pružanja usluge i u tome

50 Lopižić; Manojlović Toman, Prethodna evaluacija..., op. cit. u bilj. 6.

51 Lopižić; Manojlović Toman, Predictions..., op. cit. u bilj. 6. 
da građani nemaju dilemu koje je tijelo nadležno za pojedino pitanje, već znaju da sve mogu riješiti u županiji.

Kao što su kazali neki ispitanici, u kontekstu prijenosa poslova državne uprave na županije potrebno je uzeti u obzir i proces digitalizacije koji je posebno zaživio kod poslova kao što su matičarstvo, a dodatni impuls mu je dala i pandemija bolesti COVID-19, koja je obilježila prvu godinu obavljanja ovih poslova u županijama. Digitalizacija je pitanje budućnosti, ne samo povjerenih poslova, već i niza poslova javne uprave općenito te se može postaviti pitanje u kojoj će mjeri ona utjecati na daljnje obavljanje ovih poslova u županijama. Digitalizacija može biti faktor koji će spriječiti novi rast službenika koji obavljaju državne poslove jer će manji broj službenika moći jednostavnije obaviti isti opseg poslova. S druge strane, prenošenje poslova na razinu županija znači da proces digitalizacije više neće voditi središnja država nego svaka županija, što može dovesti do neujednačenosti među županijama u pogledu resursa koje ulažu u razvoj digitalne tehnologije, a onda i kvalitete županijskih usluga. Također, upitno je hoće li županije poticati daljnju digitalizaciju u istoj mjeri kao što bi to činila središnja država ili će prenošenje poslova županijama osujetiti daljnji proces digitalizacije. No, odgovori ispitanika upućuju na to da je upravo digitalizacija bila način prevladavanja problema manjka službenika uslijed odlaska u mirovinu, pa se može zaključiti da je decentralizacija u nekim županijama potaknula proces digitalizacije.

Provedeni intervjui pokazali su kako u pogledu nekih rezultata do kojih je ukidanje ureda državne uprave u županijama dovelo postoji suglasnost među ispitanicima i ujednačenost među županijama, no i kako o većem broju pitanja suglasnosti nema te se stanje među istraženim županijama razlikuje. Razlike u stavovima ispitanika indiciraju na određene faktore koji bi mogli biti od utjecaja na efekte ukidanja ureda državne uprave u pojedinoj županiji i stav ispitanika. Prvi faktor su menadžerske sposobnosti pročelnika koji mora znati organizirati rad tako da balansira između novih zapošljavanja i racionalizacije te kvalitete obavljanja poslova. Drugi faktor je fizička lokacija službenika. Čini se da su u županijama u kojima su bivši službenici ureda državne uprave i službenici županije locirani na istoj lokaciji olakšane suradnja i integracija u odnosu na županije u kojima su službenici dislocirani. Treći faktor je model integracije poslova jer se pokazalo da ispitanici iz županija u kojima je razina organizacijske integracije manja u pravilu imaju manje pozitivan stav o organizacijskoj promjeni od ispitanika u čijim organizacijama je primijenjen model koji dovodi do veće razine integracije. Četvrti faktor su neformalni odnosi. Čini se kako su prijašnji odnosi suradnje ureda državne uprave i županija pozitivno utjecali na proces integracije i stav ispitanika o organizacijskoj promjeni. Zadnji faktor je županov stil upravljanja koji i snosi odgovornost za obavljanje prenesenih poslova te određuje mjeru u kojoj dopušta autonomiju u radu pročelnicima. 


\section{ZAKLJUČAK}

Provedeni intervjui upućuju na neke dosadašnje pozitivne i negativne rezultate integracije poslova državne uprave u tijela županijske uprave $u$ ispitanim županijama. Pozitivni rezultati odnose se na bolja materijalna prava službenika, bolje materijalne uvjete rada te nepromijenjen ili nešto bolji položaj građana. Negativni rezultati za sada su slabiji nadzor središnje države te gubitak nadzora nad lokalnom samoupravom. Međutim, mnoga pitanja ostaju otvorena. Prvo se odnosi na smanjenje broja službenika i kvalitetu obavljanja poslova - je li racionalizacija obavljanja poslova utjecala na kvalitetu obavljanja poslova te hoće li kraj pandemije bolesti COVID-19 dovesti do ponovnog rasta broja službenika u Županijskoj upravi zbog čega će se postojeći efekt racionalizacije poništiti. Drugo se pitanje odnosi na politizaciju - hoće li promjena vlasti nakon lokalnih izbora u svibnju 2021. dovesti do promjene u upravljanju obavljanjem prenesenih poslova i jačem političkom utjecaju župana na rješavanje pojedinačnih slučajeva. Treće se odnosi na ulogu županija u budućnosti - hoće li se županije koje su veličinom mjerenom brojem službenika bile tek nešto veće od ureda državne uprave postupno pretvoriti u produžene ruke središnje države i kako će opterećenje obavljanjem poslova državne uprave utjecati na njihovu samoupravnu ulogu. Četvrto se odnosi na neujednačenosti između županija - dovode li razlike u organizaciji obavljanja prenesenih poslova državne uprave, materijalnim pravima službenika i različitom kapacitetu županija dugoročno do nejednakosti između građana.

Valja dodati kako metodološki pristup rada ima određena ograničenja koja treba uzeti u obzir prilikom tumačenja rezultata - okolnost da su intervjuirani samo pročelnici upravnih tijela kao čelnici organizacijskih jedinica koji obavljaju poslove opće uprave / imovinskopravne poslove kao specifične kategorije prenesenih poslova te okolnost da je od provedene organizacijske promjene prošlo nešto više od godinu i pol dana, a čitav je period obilježen izvanrednom društvenom situacijom uzrokovanom pandemijom bolesti COVID-19. Rezultati istraživanja odražavaju viđenje jedne skupine relevantnih aktera u samo nekim hrvatskim županijama. Iako bacaju određeno svjetlo na organizacijsku promjenu, njezin tijek i rezultate, moraju se uzeti kao nastavak započete longitudinalne evaluacije učinaka ukidanja ureda državne uprave i kao temelj za daljnja istraživanja. Predlaže se da se daljnjim istraživanjima obuhvati širi krug aktera (župane kao nositelje izvršne vlasti u županijama odgovorne za prenesene poslove, središnja tijela državne uprave, pročelnike drugih upravnih tijela, službenike koje poslove obavljaju te naposljetku građane kao korisnike) te uključe kvantitativni pokazatelji o obavljanju prenesenih poslova (npr. broj riješenih predmeta, podnesenih žalbi na donesena rješenja itd.) kako bi slika o ovoj organizacijskoj promjeni bila potpunija. 


\section{LITERATURA}

Ajduković, M.; Urbanc, K., Kvalitativna analiza iskustva stručnih djelatnika kao doprinos evaluaciji procesa uvođenja novog modela rada u centre za socijalnu skrb, Ljetopis socijalnog rada, vol. 17, br. 3, 2010., str. 319 - 352.

Congress of Local and Regional Authorities in Europe, Local and regional democracy in Croatia, https://www.coe.int/en/web/congress/-/local-and-regional-democracy-in-croatia (1. lipnja 2021.)

Koprić, I., Uloga županija u hrvatskom sustavu lokalne samouprave i uprave 1990-ih $i$ perspektive regionalizacije nakon promjena Ustava iz 2000. godine, Hrvatska javna uprava, vol. 3, br. 1, 2001., str. $63-87$.

Koprić, I.; Marčetić, G.; Musa, A.; Đulabić, V.; Lalić Novak, G., Upravna znanost - javna uprava u suvremenom europskom kontekstu, Pravni fakultet Sveučilišta u Zagrebu i Studijski centar za javnu upravu i javne financije, Zagreb, 2021.

Kuhlmann, S.; Wollmann, H., Introduction to Comparative Public Administration: Administrative Systems and Reforms in Europe, Edward Elgar, Cheltenham, 2019.

Leemans, A. F., Changing Patterns of Local Government, International Union of Local Authorities, Hague, 1970.

Lopižić, I., Dekoncentrirana državna uprava i lokalna samouprava: faktor kapaciteta, u: Musa, A. (ur.), Forum za javnu upravu. Izazovi upravljanja: decentralizacija $i$ dekoncentracija obavljanja javnih poslova, Friedrich Ebert Stiftung i Institut za javnu upravu, Zagreb, 2018., str. 25 - 40.

Lopižić, I., Uloga ureda državne uprave u hrvatskome upravno-političkom sustavu, Hrvatska i komparativna javna uprava, vol. 20, br. 3, 2020., str. 549 - 577.

Lopižić, I.; Manojlović Toman, R., Prethodna evaluacija ukidanja ureda državne uprave u županijama, Zbornik Pravnog fakulteta u Zagrebu, vol. 69, br. 5-6, 2019., str. $635-670$.

Lopižić, I.; Manojlović Toman, R., Predictions of State and County Civil Servants Regarding the County State Administration Offices Abolition: Two Sides of the Same Coin?, Central European Public Administration Review, vol. 19, br. 1, 2021., str. $41-61$.

Marčetić, G., Novo lokalno službeničko zakonodavstvo i upravljanje ljudskim potencijalima u reformiranoj lokalnoj samoupravi, u: Koprić, I., (ur.), Reforma lokalne i regionalne samouprave u Hrvatskoj, Pravni fakultet Sveučilišta u Zagrebu i Studijski centar za javnu upravu i javne financije, Zagreb, 2013.

Ministarstvo financija, Izvještaj o izvršenju državnog proračuna 2021., https://mfin. gov.hr/proracun-86/drzavni-proracun-2021-godina/3116 (1. lipnja 2021.). 
Ministarstvo financija, Izvještaj o izvršenju državnog proračuna 2018., https://mfin. gov.hr/UserDocsImages/dokumenti/proracun/drzavni2018/Posebni\%20 dioR18..pdf (1. lipnja 2021.).

Ritchie, J.; Spencer, L.; O'Connor, W., Carrying out Qualitative Analysis, u: Ritchie, J.; Lewis, J. (ur.), Qualitative Research Practice - A Guide for Social Science Students and Researchers, SAGE Publications, London, 2003., str. 219 - 262.

Škarica, M., Interplay Between the Tiers in Croatian Local Government: Who Is Winning the Interdependence Game, Hrvatska i komparativna javna uprava, vol. 20, br. 2, 2020., str. $207-240$.

Wollmann, H., Reforming Local Leadership and Local Democracy: the Case of England, Sweden, Germany and France in Comparative Perspective, Local Government Studies, vol. 34, br. 2, 2008., str. $282-283$.

\section{Propisi}

Ustav Republike Hrvatske, Narodne novine, br. 56/90., 135/97., 08/98., 113/00., 124/00., 28/01., 41/01., 55/01., 76/10., 85/10., 05/14.

Odluka o proglašenju promjene Ustava Republike Hrvatske, Narodne novine, br. $113 / 00$.

Zakon o izmjenama i dopunama Zakona o sustavu državne uprave, Narodne novine, br. 59/01.

Zakon o sustavu državne uprave, Narodne novine, br. 66/19.

Zakon o lokalnoj i područnoj (regionalnoj) samoupravi, Narodne novine, br. 33/01., 60/01., 129/05., 109/07., 125/08., 36/09., 36/09., 150/11., 144/12., 19/13., 137/15., 123/17., 98/19., 144/20.

Zakon o službenicima i namještenicima u jedinicama lokalne i područne (regionalne) samouprave, Narodne novine, br. 86/08., 61/11., 04/18., 112/19.

Zakon o izvršavanju Državnog proračuna Republike Hrvatske za 2021. godinu, Narodne novine, br. 34/20.

Odluka o ustrojstvu i djelokrugu upravnih tijela Primorsko-goranske županije, Službeni glasnik Primorsko-goranske županije, br. 29/19.

Odluka o ustrojstvu i djelokrugu upravnih tijela Sisačko-moslavačke županije, Službeni glasnik Sisačko-moslavačke županije, br. 29/19.

Odluka o ustrojstvu i djelokrugu upravnih tijela Istarske županije, Službene novine Istarske županije br. 26/19.

Odluka o ustrojstvu i djelokrugu upravnih tijela Karlovačke županije, Županijski glasnik br. 57b/19. 
Odluka o ustrojstvu i djelokrugu upravnih tijela Dubrovačko-neretvanske županije, Službeni glasnik Dubrovačko-neretvanske županije, br. 14/19.

Odluka o ustrojstvu i djelokrugu upravnih tijela Splitsko-dalmatinske županije, Službeni glasnik Splitsko-dalmatinske županije, br. 161/19.

Odluka o ustrojstvu i djelokrugu upravnih tijela Ličko-senjske županije, Županijski glasnik Ličko-senjske županije, br. 32/19.

Odluka o ustrojstvu i djelokrugu upravnih tijela Požeško-slavonske županije, Požeško-slavonski županijski glasnik, br. 9/19.

Odluka o ustrojstvu i djelokrugu upravnih tijela Brodsko-posavske županije, Službeni vjesnik Brodsko-posavske županije, br. 28/19.

Odluka o ustrojstvu i djelokrugu upravnih tijela Bjelovarsko-bilogorske županije, Županijski glasnik br. 7/19.

Odluka o ustrojstvu i djelokrugu upravnih tijela Koprivničko-križevačke županije, Službeni glasnik Koprivničko-križevačke županije, br. 18/19.

Odluka ustrojstvu i djelokrugu Virovitičko-podravske županije, Službeni glasnik br. 7/19.

Odluka o ustrojstvu i djelokrugu upravnih tijela Krapinsko-zagorske županije, Službeni glasnik Krapinsko-zagorske županije br. 52/19.

Odluka o ustrojstvu i djelokrugu upravnih tijela Međimurske županije, Službeni glasnik Međimurske županije, Službeni glasnik Međimurske županije br. 19/19.

Odluka o ustrojstvu i djelokrugu upravnih tijela Varaždinske županije, Službeni vjesnik Varaždinske županije, br. 82/19

Odluka o ustrojstvu i djelokrugu upravnih tijela Zadarske županije, Službeni glasnik Zadarske županije br. 25/19.

Odluka o ustrojstvu i djelokrugu upravnih tijela Vukovarsko-srijemske županije, Službeni glasnik Vukovarsko-srijemske županije br. 20/19.

Odluka o ustrojstvu i djelokrugu upravnih tijela Šibensko-kninske županije, Službeni vjesnik Šibensko-kninske županije, br. 17/19.

Odluka o ustrojstvu i djelokrugu upravnih tijela Osječko-baranjske županije, Županijski glasnik br. 15/19.

Odluka o ustrojstvu i djelokrugu upravnih tijela Zadarske županije, Službeni glasnik Zadarske županije, br. 25/19.

Odluka o ustrojstvu i djelokrugu upravnih tijela Zagrebačke županije, Glasnik Zagrebačke županije br. 43/19.

Uredba o unutarnjem ustrojstvu ureda državne uprave u županijama, Narodne novine, br. $84 / 18$. 


\section{DODATAK 1}

Pitanja za intervju s pročelnicima upravnih tijela u okviru kojih se obavljaju povjereni poslovi opće uprave

1. Molimo ukratko opišite proces preuzimanja poslova ukinutih ureda državne uprave u Vašoj županiji (kako su tekle pripreme, koliko je službenika bilo uključeno u pripreme, koji su problemi pri tome postojali).

2. Na koji ste način organizirali obavljanje povjerenih poslova ureda državne uprave (koliko je službenika iz ureda ukupno preuzeto, koliko u Vaš upravni odjel, da li se mijenjao njihov opis poslova, da li ste zapošljavali nove službenike, gdje su prostorno locirani preuzeti službenici)?

3. Koji su najveći izazovi prilikom preuzimanja poslova ureda državne uprave? Što Vam stvara najveći problem u radu?

4. Koje poslove obavlja Vaš upravni odjel? Da li je i na koji način je preuzimanje poslova ureda države uprave utjecalo na obavljanje poslova samoupravnog djelokruga Vašeg upravnog odjela? Da li i u čemu vidite razliku u obavljanju između povjerenih poslova i samoupravnih poslova županije?

5. Da li su se preuzeti službenici ukinutih ureda integrirali u rad županijske uprave? U kojim aspektima se njihov radno-pravni položaj promijenio? U kojoj mjeri surađujete s drugim upravnim odjelima?

6. U kojoj mjeri ste prije surađivali s uredima državne uprave? Da li nakon preuzimanja poslova intenzivnije komunicirate i surađujete s tijelima državne vlasti?

7. Smatrate li da je reforma ukidanja ureda državna uprave u županijama dobro provedena? Što se u tom pogledu moglo učiniti drugačije?

8. Kako biste danas ocijenili ukidanje ureda državne uprave u županijama? Da li su se ispunila Vaša početna očekivanja? Da li su se pojavili neočekivani problemi? 


\section{DODATAK 2}

\section{Izjave ispitanika}

\section{Tematsko područje 1 - Tijek i dosadašnji rezultati ukidanja ureda državne uprave}

Izjava I - "Bili su organizirani sastanci s Ministarstvom uprave. Oni zaista jesu sa svoje strane dali brojne upute, naputke vezano uz preuzimanje. Onda su bili organizirani sastanci u Hrvatskoj zajednici županija gdje smo razmjenjivali nekakve prakse... Surađivali smo s uredom države uprave, s predstojnikom i zamjenikom, sa voditeljima njihovih odjela." ISP9

Izjava 2 - "Već smo mi početkom 2019. na kolegijima predstojnika (ureda državne uprave u županijama - istaknule autorice) počeli pričati okvirno da će se uredi ukinuti, znači bilo je nekakvih naznaka. A intenzivno smo se uključili u postupak, znači u te pripremne radnje vezane za povjeravanje poslova, onda kada je izglasan Zakon o sustavu državne uprave, mislim da je to bilo 8.7.2019., kada je stupio na snagu. Tada smo zapravo mogli raditi te pripreme. Znači u tom razdoblju napravili smo analizu. Ja sam bila osobno, znači intenzivno kao predstojnica bila uključena, bio je župan, njegovi zamjenici, pročelnici, pročelnik ureda župana, isto tako bilo je Ministarstvo uprave, ono je imenovalo koordinatore za svaku pojedinu županiju." ISP4

Izjava 3 - "Šest (zaposlenika je prihvatilo ponudu za odlazak u mirovinu - istaknule autorice), ništa više, jako malo. Jer ako ćemo biti iskreni plaće službenika koji su radili u uredima državne uprave u našoj županiji u prosjeku su svima povećane za $80 \%$." ISP5

Izjava 4 - "Bilo je puno ljudi koji su ispunjavali te uvjete za otpremnine i za odlazak iz službe. Tako da je nama otišlo iz sustava 53 službenika, točno pola." ISP4

Izjava 5 - "Mi smo imali u prvom mjesecu ta rješenja. 22.1. sam ja dobila. U 12. mjesecu imali smo sve spremno." ISP4

Izjava 6 - "Ja sam kao pročelnik dobio rješenje sa 1.4. i kolegice iz računovodstva, a svi ostali su dobili sa 1.5." ISP6

Izjava 7 - "29 je otišlo u mirovinu uz ove stimulirajuće otpremnine. Od tog broja u službu za opću upravu preuzeto je 49 službenika, a 15 ih je čak otišlo uz otpremninu. Tako da smo mi zaista bili deficitarni sa kadrom... (zaposleno je 10 novih službenika - istaknule autorice) Ja sam rekao da imam potrebu za tim radnim mjestima." ISPI

Izjava 8 - "Evo ovako, tu je nama i korona pomogla malo, ja moram priznati, u protekloj godini... Mi smo zaposlili samo dva nova službenika nužna da pokriju 
obavljanje poslova, a ovo smo drugo nekako preraspodijelili na naše službenike i na postojeće službenike ureda državne uprave... Sigurno u nekoj normalizaciji da će tu trebati dodatno zaposliti neke službenike." ISP9

Izjava 9 - "Ne, u tom smislu nismo (zapošljavali nove službenike - istaknule autorice). Imali smo nešto prijema na određeno vrijeme, ovi ljudi što nam rade na obrani od poplava, to je ovaj povećani opseg posla i nešto vježbenika. Nismo imali sad u smislu otišlo nam je ne znam, troje matičara, da smo tri nova primili. Drugi su uskakali na njihova mjesta." ISP4

Izjava 10 - "Svi obavljaju posao gdje su i zatečeni, na istim mjestima, nismo ih premještali." ISP9

Izjava 11 - "Svima se plaća povećala, ali u našoj županiji nažalost nisu velike plaće tako da to nisu bila neka drastična povećanja. Kod nas je plaća ista (kao službenicima koji rade poslove samoupravnog djelokruga županije - istaknule autorice)." ISP2

Izjava 12 - "Plaće jesu povećane, ali je županija napravila po meni jedan nepravičan potez tako da oni imaju $10 \%$ manje plaće nego ostali službenici u samoj upravi... Službenici imaju manje plaće od službenika samouprave pa to stvara nezadovoljstvo. Plaće su manje za desetak posto (osim pročelniku) iako je država osigurala dostatna sredstva." ISP3

Izjava 13 - "Naša neka zamisao je bila da kada se preuzmi djelatnici kod nas, da svi krenu s nekim najnižim koeficijentom te stručne spreme koju imaju. I onda smo to mijenjali ovisno o tome kako se tko pokazao. Znači nismo automatski raspoređivali. Kod nas je i inače, mislim da je i u većini županija tako, nije da sad svaki stručni suradnik ima jednaki koeficijent. Uvijek postoji raspon, razred. Nije to neka velika razlika ali nešto malo je. Znači krenuli su s nekim najnižim koeficijentima i onda smo to kroz evo godinu i po, nekima se nije mijenjao koeficijent, a nekima je već koeficijent porastao. Htjeli smo ih na taj način stimulirati i nismo htjeli automatski dodjeljivati koeficijente kao što imaju županijski djelatnici dok ne vidimo malo kako to funkcionira, kako obavljaju posao, kako će se tko prilagoditi i biti spreman na neku suradnju. I uglavnom su oni svi napredovali, ja ne mogu ništa reći, neki nisu. Ali i s tim našim najnižim koeficijentima oni nisu bili na gubitku." ISP7

Izjava 14 - "Čini mi se da su zadovoljniji zato što su im materijalna prava nešto bolja, lakše ih ostvaruju. Od banalnih stvari - ured državne uprave nije imao ni wc papira. Pa je, te javne nabave su se provodile na državnoj razini pa je to nekako tako loše u tom smislu funkcioniralo. Nisu imali nekog previše samostalnog prava da odluče o nečemu. Recimo i o novom zapošljavanju, recimo je hitno novo zapošljavanje, a nije bilo predviđeno početkom godine tamo u nekom njihovom planu. Tako da sada brže rješavamo takve probleme i zadovoljni su jer su im materijalna prava bolja." ISP9 
Izjava 15 - "Nema više nas i njih.” ISP8

Izjava 16 - "Na početku je ovako bilo priča onako vi, mi i to, ali sada se to već gubi." ISP9

Izjava 17 - "I uvijek imate tako u početku taj odnos mi vi, oni, naši tako to, ovu godinu kako novaca nije bilo da nisu dobili zbog nas, je li, ni božićnicu ni uskrsnicu, ništa pa smo mi bili krivi svemu." ISP2

Izjava 18 - "Recimo županija nema ispostave, oni imaju izdvojena tijela ali nemaju ispostave. Znači imaju jednu zajedničku pisarnicu. Mi smo u uredu državne uprave imali tako da svaka ispostava ima svoju pisarnicu. Znači tu oko tog uredskog poslovanja su se baš stvarali onako veliki problemi." ISPI

Izjava 19 - "Jedna tema koja je meni bitna i koja je stvorila tu problem su te ispostave... Mi smo tražili od ministarstva da ZLP(R)S na neki način izmijeni jednako tako da tako možemo organizirati rad, međutim nisu i to nam stvara problem jer službenici su morali odlučiti hoće li raditi imovinsko pravne poslove koji je u upravnom odjelu za zaštitu okoliša ili će raditi gospodarske koji je u upravnom odjelu za gospodarstvo. I tu se stvorilo to da nam fali ljudi na nekim poslovima, a negdje tu netko možda nema toliko popunjen posao za ovo što radi." ISP9

Izjava 20 - "Mi smo startali sa malim brojem službenika s njihove strane i neke lokacije su bile jako problematične. Ne znam, problem vam je kad na nekoj lokaciji nemate niti jednog matičara." ISP8

Izjava 21 - "Vjerujte mi da je teže doći do kvalitetne SSS nego visoke." ISP8

\section{Tematsko područje 2 - Integracija prenesenih poslova, horizontalna i vertikalna integracija}

Izjava 22 - "To meni nema smisla, oprostite, ali to nema smisla. To onda ništa niste dobili." ISP2

Izjava 23 - "Mislim da je više razloga da se oni rasporede po upravnim odjelima županije, da je više tu pluseva nego da budu zasebni." ISP9

Izjava 24 - "Mi smo išli da to bude po upravnim područjima. Da poslovi gospodarstva pripadnu upravnom odjelu za gospodarstvo, jel tako nekako tamo i pripadaju. Poslovi vezani za školstvo da po prirodi stvari budu recimo u njihovom odjelu za školstvo jer je to sve jedna srodna problematika." ISP4

Izjava 25 - "Mislim dakle ja sam sigurna u to 101\%. Zašto? Zato što ne može se miješati kruške i jabuke. To je i dalje posao državni posao, to je posao koji mi za državu obavljamo, ali naš posao koji je u samoupravnom djelokrugu županije je i dalje ostao naš posao i isti posao, a ovo je posao koji je potpuno 
različit od posla kojeg smo mi obavljali... Mislim da bi bilo jednostavnije to ostalo u jednom upravnom odjelu koji bi koordinirao sve te poslove ajmo reći iz jednog sjedišta. Puno kvalitetnije i jednostavnije..." ISP5

Izjava 26 - "A gledajte, da nam je bilo bolje i lakše prije apsolutno je. Pogotovo u ovom upravnom odjelu gdje nas je bilo, ne znam ni ne sjećam se, trideset i nešto, a sad nas je 96. Nije isto." ISP8

Izjava 27 - "Zadovoljni su... Možda nam je prednost... I što nisu dobili osobu na čelu koja nije iz tog sustava. Nego mene koji znam taj sustav, koji sam vodio tu službu 3-4 godine. To im je zato velika prednost isto." ISPI

Izjava 28 - “...mi se kao upravni odjel zaista razlikujemo. Oni svi govore o nekakvim projektima, investicijama. Mislim mi realno provodimo poslove državne uprave, mi nemamo nikakve investicije." ISPI

Izjava 29 - "Mi smo ovdje fokusirani isključivo na rad sa strankama. Znači županija ima drugu tehnologiju funkcioniranja. Ona funkcionira na sastancima, vezano uz probleme koje ima na projektima i na radu svojih ustanova, to su ustanove škole, bolnice i lučka uprava..." ISP3

Izjava 30 - “...da su poslovi bitno različiti jesu, tamo je upravni postupak, postupak ide kako ide, nema tu neke kreativnosti, županija ima poslove gdje možete biti kreativni, nije to besplatna pravna pomoć." ISP8

Izjava 31 - "Imamo kolegije kod župana jednom mjesečno tako da... Moja služba je uvijek nekako stavljena van, i dalje je to državna uprava.” ISPI

Izjava 32 - "Kad smo moja kolegica i ja išle na te kolegije, mi smo se samo gledale šta mi radimo ovdje. Oni su samo pričali o nekim projektima, ovome, onome, mi ništa." ISP2

Izjava 33 - "Mi na županiju šaljemo plan rada koji nitko ne čita i damo izvješće o radu koje opet nitko ne čita. Tako da ja idem na sastanke samo kad je kolegij." ISP3

Izjava 34 - “... imali smo sastanak sa svim načelnicima i gradonačelnicima općina u kojima su matični uredi.” ISP6

Izjava 35 - "Da nas drugostupanjska tijela stvarno prate, nadziru, upućuju, nisam vam to sigurna. Mislim da je to više stihijski i pojedinačno nego organizirano." ISP2

Izjava 36 - "Što se tiče mene i mojih preuzetih poslova, ne. To se stvarno svodi na 2-3 maila više na nekoj mjesečnoj razini... Ne znam je li to zbog cijele te situacije, te pandemije pa su imali svojih briga, ili su imali dovoljno povjerenja u nas, zadovoljni su kako to obavljamo pa se ne petljaju previše." ISP7

Izjava 37 - "Ne, ne podnosimo (izvješća Ministarstvu - napomena autorica), ali mislim, oni su nama nadređeni što se tiče žalbi, ali znaju nas tražiti neke 
podatke, recimo Ministarstvo pravosuđa nas zna tražiti podatke npr. koliko imamo povrata imovine u određenom segmentu." ISP4

Izjava 38 - "Malo manje kontaktiramo, manje oni nas kontaktiraju, ali inače to zavisi od službenika i rješavanja predmeta." ISP6

Izjava 39 - "Sve vam to ovisi o ranijim odnosima, ja mislim više o tome nego o organiziranosti središnjih tijela.” ISP2

Izjava 40 - "Onaj koji obavlja prenesene poslove koliko je razgovarao prije, razgovara i sada, ali mi drugi ne nešto previše." ISP8

Izjava 41 - “... prvenstveno nadzor. To je nešto što je po meni rak-rana ovog ustrojstva jer ja sam tu osobno baš žalosna jer smo mi puste godine uložili u nadzor općih akata jedinica lokalne samouprave, mi smo učili i učili i upozoravali prije nego nam je to zakon nalagao i govorili im što treba ispraviti. $\mathrm{Na}$ kraju smo došli do toga da gotovo nije bilo grešaka kad bi oni nama poslali akt. Naši ljudi su se izvještili i ovaj nadzirali su to. I sad dođete u situaciju da sad to nadziru središnja tijela. Ja sam 100\% sigurna, ne 90 da oni to ne rade. Možda MU radi nadzor u svom dijelu. Niti su ekipirani niti ja vidim da su oni ustrojili neke jedinice da to nadziru, ne znam." ISP2

\section{Tematsko područje 3 - Subjektivna ocjena o dosadašnjim efektima}

Izjava 42 - "Pa ja konkretno za svoju službu smatram da su očekivanja ispunjena. Mislim, imamo neku neovisnost u obavljanju poslova, ljudi su dobili bolje materijalne uvjete. Ja gledam recimo poslovi nabavke, od uredske opreme, tonera, sve to nekako brže ide ovdje." ISPI

Izjava 43 - "Ovim izmjenama koje su provedene suprotno Strategiji razvoja javne uprave, napravljen je jedan kupus u režiji nekompetentnih ljudi." ISP3

Izjava 44 - "Mi nemamo nikakva mjerila po kojima ćemo mi reći šta i koliko količinski se radi... Nitko nije izmjerio količinski broj predmeta, broj ljudi koji je potreban za rješavanje tih predmeta, upravna područja koja su potrebna da budu u uredu državne uprave, a koja nisu... I sad ste vi preslikali taj naš posao na lokalnu. Ništa. Praktički se ništa nije dogodilo. Ja ne znam, vjerojatno ste i pročitali ono što je bio cilj reforme 17-20 što je ministarstvo uprave, akcijski plan i to, to je skroz išlo u drugom smjeru, znači išlo je u smjeru jačanja ureda upravo što smo mi jedina prvostupanjska tijela bili na terenu, jel. A na kraju iz nekog razloga, već sad znamo i kojeg ali nije bitno, se to promijenilo." ISP2

Izjava 45 - "Pa da se dulje pripremala, pitanje što bi od nje bilo. Nekad je možda potrebno presjeć stvari." ISP7

Izjava 46 - "Ja mislim da se nije brzo provela, možda se ne bi ni provela, mislim da je dobro da se brzo provela." ISP9 
Izjava 47 - "Zašto gradovi nisu ništa dobili? To je isto blesavo, nisu samo jedinice lokalne županije. Gradovi se u tom smislu nisu niti probudili, pazite nisu oni ni tražili ništa, oni nisu imali pojma uopće da bi bilo dobro da nešto pređe i kod njih, dio školstva ne znam, predškolski odgoj, ionako oni imaju te vrtiće, a mi dajemo minimalne tehničke uvjete za otvaranje vrtića. Zašto to oni nisu mogli raditi. Mogli su." ISP2

Izjava 48 - "Također trebalo je napraviti kriterije koji bi određeni poslovi državne uprave eventualno trebali prijeći na županije s obzirom na neku logiku postojanja županija. I sada je značajan dio državne uprave izvan nadležnosti županija. Osim spomenutih inspekcija tu su i poljoprivredne službe koje su bitnije županijama za razvoj nego, npr., matičari." ISP3

Izjava 49 - "Sada su županije postale Uredi državne uprave, a razvojne uloge županija su zanemarene... Suprotno nekoj logici ustavne pozicije županije koja je ustavom jedinica područne samouprave. Mi ako sad analiziramo županiju ona više nije jedinica samouprave nego jedinica državne uprave... To nije zakonska pozicija županije kao što je to ranije bilo kad je županija bila jedinica uprave i samouprave. To nije dobro iz nekih relacija i odnosa Vlade koja na čitavom području gleda poslove državne uprave i županija koje bi trebale biti nositelji razvoja u onim područjima u kojima im je to zakon dao." ISP3

Izjava 50 - "Jedan od faktora (dobre provedbe - istaknule autorice) je ta suradnja državne vlasti s područnom samoupravom. Da je prvi korak neka normalna komunikacija." IPS4

Izjava 51 - "Mi smo i prije, znači ima puno ljudi koji su i prije radili u županiji pa onda surađivali s tim kolegama iz županija tako da se mi i inače međusobno znamo." ISP2

Izjava 52 - "Oni su dobili na važnosti. Narasli su jako." ISPI

Izjava 53 - "On (župan - istaknule autorice) je dobio na određeni način obaveze i odgovornosti, ali na određeni način i ovlast." ISP5

Izjava 54 - "Dobio je još ljudi, još poslova, naravno odgovorniji je za obavljanje više poslova na području županija." ISP9

Izjava 55 - "Ne vidim ja neki efekt ovog. Osim očuvanja županija kao takvih da ne kaže netko eto nemate smisla." ISP2

Izjava 56 - "Ta kompletna reorganizacija kad se radila se radila tak na brzinu da se to sve pretumba u županiju da bi se na neki način ojačala pozicija županija u tom hrvatskom prostoru." ISP6

Izjava 57 - "Mislim da je to najveći problem spajanja ureda države uprave s županijama, što previše utjecaja politike ima. Ja zasad nemam neka loša iskustva vezano za petljanje u posao (od strane župana - istaknule autorice)... Ali realno 
postoji velika mogućnost... To ovisi isto o osobi župana. Recimo moj župan toliko nema potrebu miješanja, ali doći će neki drugi, pa izbori su. Znači svake četiri godine će to biti neke promjene. To službenici ne bi smjeli osjetiti i imati utjecaja na njihov rad." ISPI

Izjava 58 - "A što se tiče župana, naravno da je bila tu politička uloga dosta jača i ako on je osoba koja voli se uplitati i naređivati to bi onda trebao biti problem. Međutim, bez obzira šta on kaže, ako se nešto prema zakonu mora provesti tako i tako, to ne može nitko promijeniti." ISP2

Izjava 59 - "Mi ne možemo van zakona, zna se kaj je to ZUP, podnošenje zahtjeva stranke, prikupljanje dokaza, minimalno 15 dana, kod složenih predmeta 30. Jednostavno rečeno moramo se ponašati slova zakona." ISP6

Izjava 60 - "Za građane ista je efikasnost... Ja nisam osjetila niti nekakav rezultat, gotovo isti s duplo manje službenika." ISP4

Izjava 61 - "Kvalitetnije je jer je na jednoj lokaciji puno više usluga, prije su bile dvije lokacije, sad je jedna lokacija." ISP8

Izjava 62 - "Pa ja mislim da im je (gradanima - istaknule autorice) bolje. Mi nismo još dobili nikakvu pritužbu od nikoga, dobili smo samo pohvalu i preko ministarstava što su slali građani... Jer su nekad u jedan ured morali ić vadit papir da bi ga predali u drugi ured. Mislim nama je sad sve dostupno, naravno da ne smijemo i ne želimo tražit stranke da vade bespotrebno papire ako su ti papiri nama dostupni u okviru naših nadležnosti." ISP7

Izjava 63 - "Ma gledajte, učinkovitiji jesmo, ali to nije samo zbog županije to je zbog mnogih faktora, to je zato što APIS bolje radi, što je elektronika bolja, što smo dobili godinu dana i uspostavili e-mailove da građani mogu mailom poslati zahtjev, imamo sve obrasce na web stranicama itd." ISP4 
Summary

Iva Lopižić*

Romea Manojlović Toman**

\section{INTEGRATION OF COUNTY STATE ADMINISTRATION OFFICES' AFFAIRS IN COUNTY ADMINISTRATION: THE RESULTS SO FAR}

In January 2020, the county state administration offices, as former first-instance state administration bodies, ceased to operate. By legislative amendments of October 2019, most of their tasks were transferred to the counties' delegated scope of affairs. The paper presents the peculiarities of the legal regime of delegated scope of affairs and it introduces the organizational forms that the counties are using in order to perform the delegated tasks. The first results of the abolition of county administrative offices are evaluated on the basis of semi-structured interviews conducted with the heads of county administration bodies responsible for general administration affairs. The results obtained so far are classified into three categories. The first category consists of the positive results of this organizational change: better material rights of employees, better working conditions and unchanged or slightly improved position of citizens. The second category consists of the negative results: weaker control exercised by the central government and the loss of control over general acts of units of local self-government. The third category consists of open questions: whether there will be a new increase in the number of employees, or whether their current reduction will affect the quality of work; what is the position of the county governor and whether politicization will increase; what is the future role of counties and whether there can be inequality in the performance of delegated state tasks between counties. The paper represents the basis for further evaluation studies on the abolition of county state administration offices and opens the doors for further research.

Keywords: abolition of county state administration offices, delegated scope of affairs, organizational forms for the execution of delegated scope of affairs, semi-structured interviews, heads of county administrative bodies

* Iva Lopižić, Ph. D., Postdoctoral Researcher, Faculty of Law, University of Zagreb, Trg Republike Hrvatske 14, 10000 Zagreb; iva.lopizic@pravo.hr;

ORCID: orcid.org/0000-0002-1157-0602

* Romea Manojlović Toman, Ph. D., Associate Professor, Faculty of Law, University of Zagreb, Trg Republike Hrvatske 14, 10000 Zagreb; romea.manojlovic@pravo.hr; ORCID: orcid.org/0000-0002-0292-0180 